\title{
Adverse Reactions to Metal on Metal Are Not Exclusive to Large Heads in Total Hip Arthroplasty
}

\author{
Adolph V. Lombardi Jr MD, Keith R. Berend MD, Joanne B. Adams BFA, \\ Keri L. Satterwhite
}

Published online: 23 October 2015

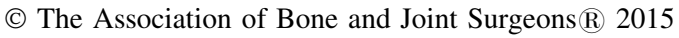

\begin{abstract}
Background There is some suggestion that smaller diameter heads in metal-on-metal total hip arthroplasty (MoM THA) may be less prone to the adverse reactions to metal debris (ARMD) seen with large-diameter heads.

Questions/purposes We reviewed our population of patients with small head $(\leq 32 \mathrm{~mm})$ MoM THA to determine (1) the frequency of ARMD; (2) potential risk factors for ARMD in this population; and (3) the etiology of revision and Kaplan-Meier survivorship with revision for all causes.

Methods Small-diameter head MoM devices were used in 9\% (347 of 3753) of primary THAs during the study period (January 1996 to March 2005). We generally used these implants in younger, more active, higher-demand patients. Three hundred hips (258 patients) had MoM THA using a
\end{abstract}

The institution of one or more of the authors (AVL, KRB, JBA, KLS) has received funding from Biomet, Inc (Warsaw, IN, USA), Pacira Pharmaceuticals Inc (Parsippany, NJ, USA), and Orthosensor (Dania Beach, FL, USA). One of the authors certifies that he (AVL) has or may receive payments or benefits, during the study period, an amount of more than USD 1,000,001 from Biomet, Inc, an amount of USD 10,000 to USD 100,000 from Innomed, Inc (Savannah, GA, USA), an amount of less than USD 10,000 from Pacira Pharmaceuticals Inc, and an amount of less than USD 10,000 from Orthosensor. One of the authors certifies that he (KRB) has or may receive payments or benefits, during the study period, an amount of more than USD 1,000,001 from Biomet, Inc.

All ICMJE Conflict of Interest Forms for authors and Clinical Orthopaedics and Related Research ${ }^{\mathbb{R}}$ editors and board members are on file with the publication and can be viewed on request.

Clinical Orthopaedics and Related Research ${ }^{\mathbb{R}}$ neither advocates nor endorses the use of any treatment, drug, or device. Readers are encouraged to always seek additional information, including FDA approval status, of any drug or device before clinical use.

Each author certifies that his or her institution approved the human protocol for this investigation and that all investigations were titanium modular acetabular component with a cobaltchromium tapered insert and were available for review with minimum 2-year followup (mean, 10 years; range, 2-19 years). Complete followup was available in $86 \%$ of hips (300 of 347). Clinical records and radiographs were reviewed to determine the frequency and etiology of revision. Kaplan-Meier survivorship analysis was performed. Results ARMD frequency was 5\% (14 of 300 hips) and represented $70 \%$ (14 of 20) of revisions performed. Using multivariate analysis, no variable tested, including height, weight, body mass index, age, cup diameter, cup angle, use of screws, stem diameter, stem type, head diameter, preoperative clinical score, diagnosis, activity level, or sex, was significant as a risk factor for revision. Twenty hips have been revised: two for infection, four for aseptic loosening, and 14 for ARMD. Kaplan-Meier analysis

conducted in conformity with ethical principles of research. This work was performed at Joint Implant Surgeons, Inc, New Albany, OH, USA

A. V. Lombardi Jr, K. R. Berend, J. B. Adams, K. L. Satterwhite Joint Implant Surgeons, Inc, New Albany, OH, USA

A. V. Lombardi Jr, K. R. Berend

The Ohio State University Wexner Medical Center, Columbus, $\mathrm{OH}$, USA

A. V. Lombardi Jr, K. R. Berend

Mount Carmel Health System, New Albany, OH, USA

A. V. Lombardi Jr ( $\square)$

Joint Implant Surgeons, Inc, 7277 Smith's Mill Road, Suite 200, New Albany, OH 43054, USA

e-mail: lombardiav@joint-surgeons.com 
revealed survival free of component revision for all causes was $95 \%$ at 10 years (95\% confidence interval [CI], 91\%$97 \%), 92 \%$ at 15 years (95\% CI, 87\%-95\%), and $72 \%$ at 19 years (95\% CI, 43\%-90\%), and survival free of component revision for aseptic causes was $96 \%$ at 10 years $(95 \% \mathrm{CI}$, $92 \%-98 \%), 92 \%$ at 15 years $(95 \% \mathrm{CI}, 88 \%-95 \%)$, and $73 \%$ at 19 years $(95 \%$ CI, $43 \%-90 \%)$.

Conclusions The late onset and devastating nature of metal-related failures is concerning with this small-diameter MoM device. Although the liner is modular, it cannot be exchanged and full acetabular revision is required. Patients with all MoM THA devices should be encouraged to return for clinical and radiographic followup, and clinicians should maintain a low threshold to perform a systematic evaluation. Symptomatic patients should undergo thorough investigation and vigilant observation for ARMD.

Level of Evidence Level IV, therapeutic study.

\section{Introduction}

Early results with second-generation metal-on-metal (MoM) bearings using $28-\mathrm{mm}$ and $32-\mathrm{mm}$ heads in THA were promising $[9,11,29,30]$. In a multicenter prospective randomized trial that included our institution, results with a small-diameter MoM THA at minimum 5-year followup (mean, 5.7 years; range, 5-8 years) were excellent with no acetabular revisions, failures, or dislocations with either the MoM study device or metal-on-polyethylene control group [30]. However, there are no other published reports with longterm followup of the device used in the current study. In an effort to further improve stability and reduce frequency of dislocation, use of small-diameter MoM bearings gave way to MoM designs with increasing head diameters. However, large head MoM THAs have exhibited high rates of loosening and adverse reactions to metal debris (ARMD) with many failures occurring early [1, 6, 13, 17, 18, 26, 28, 37, 46, 52]. We recently reported our results with large head MoM THA at minimum 2-year followup (mean, 7 years; range, 2-12 years) and observed a higher than expected rate of revision (7.5\% [108 of 1440]) with the majority of failures secondary to ARMD (48\% [47 of 108]) and lack of ingrowth (31\% [34 of 108]) [28]. Risk factors for component revision were younger age at surgery, higher cup angle of inclination, and female sex. Revisions for ARMD can be complex with extensive bone loss and damage to the surrounding soft tissue encountered intraoperatively and prone to complications and rerevisions [38, 47, 51].

Some reports have suggested that small-diameter MoM THA may be immune to ARMD [4, 19, 22, 31, 34, 35, 40, 43], because early failures have been rare. However, not all devices, even within a given classification, will perform exactly the same. Most studies with long-term followup of small-diameter MoM THA report on a single bearing design, the Metasul (Sulzer Medica, now Zimmer Biomet, Warsaw, IN, USA, and Winterthur, Switzerland), which was introduced in 1988 and has the broadest clinical experience. Longer followup is required for patients with all types of small-diameter MoM THA, particularly because these devices were often used in younger, more active patients who will have longer exposure.

We therefore reviewed our population of patients with small-diameter head $(\leq 32 \mathrm{~mm})$ MoM THA to determine (1) the frequency of ARMD; (2) potential risk factors for ARMD in this population; and (3) the etiology of revision and Kaplan-Meier survivorship with revision for all causes and for aseptic loosening.

\section{Patients and Methods}

This retrospective study was approved by an independent institutional review board. A query of our practice's arthroplasty registry revealed 299 patients (347 hips) treated with cementless primary or conversion THA using a modular MoM bearing (M2a Taper; Biomet, Warsaw, IN, USA) (Fig. 1). Twenty-two patients (22 hips) were operated on from January 1996 to July 1998 as part of a multicenter US Food and Drug Administration (FDA) investigational device exemption (IDE) study and were included in reports at short- and midterm followup [29, 30]. The other 325 patients were operated on after US FDA clearance of the device in July 2000 until March 2005. Use of this device was 9\% (347 of 3753) of primary and conversion THAs during the overall study period (January 1996 to March 2005) with metal-on-polyethylene used in 2408 (64\%), other types of MoM bearings in 808 (22\%), ceramic-on-polyethylene in $150(4 \%)$, and ceramic-on-ceramic in 40 (1\%). Of the 347 hips, 18 nonrevised hips were in 15 patients who either died within 2 years postoperatively or had not returned for minimum 2-year followup before their death. Patient deaths were determined by review of medical records, notification by surviving family members, search of online obituaries, and search of the Social Security death registry. In addition, 29 nonrevised hips were in 26 patients who were lost to contact before completing 2-year followup, leaving a cohort of 300 hips $(86 \%)$ in 258 patients with minimum 2-year followup available for review. Fifty patients (59 hips) with minimum 2-year followup died during the study period, and their most recent clinical findings are included in our results.

The main indications for the use of MoM THA during the study period were in patients who were younger, more active and high demand, and were perceived to have potential to benefit from an alternate bearing. 


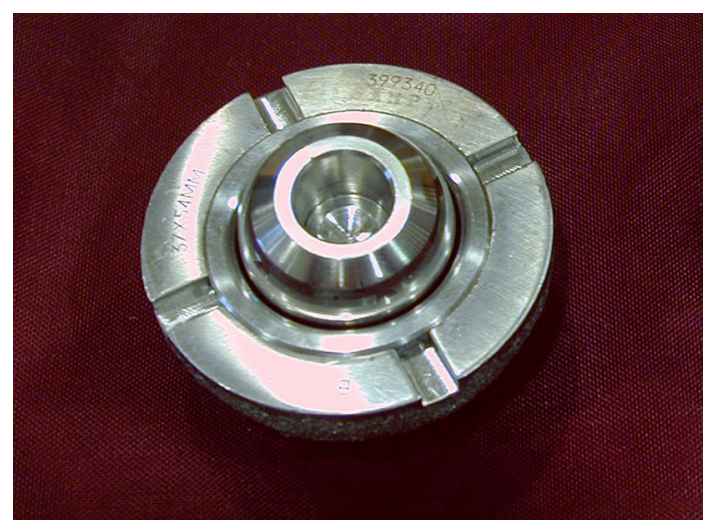

Fig. 1 The bearing used in the current study was the M2a Taper (Biomet, Warsaw, IN, USA), featuring a wrought cobalt-chromium tapered insert that is impacted into a titanium porous plasma spraycoated outer shell and articulated with a wrought cobalt-chromium modular femoral head. Acetabular component outer sizes ranged from $48 \mathrm{~mm}$ to $70 \mathrm{~mm}$ in 2-mm increments. Available head diameters were $28 \mathrm{~mm}$ and $32 \mathrm{~mm}$, each with seven neck length options from -6 to $+12 \mathrm{~mm}$. Printed with permission of Joint Implant Surgeons, Inc, New Albany, OH, USA.

A contraindication for use of MoM devices was in patients known to have renal insufficiency, as recommended in some studies [7, 15, 32, 33]. Use of MoM devices gradually shifted from small-diameter head devices to larger diameter head devices, which were touted to provide greater stability as the large head designs became available with no change in indications. Mean patient age was 56 years (range, 24-86 years; SD 11), mean body mass index was 31 $\mathrm{kg} / \mathrm{m}^{2}$ (range, $18-64 \mathrm{~kg} / \mathrm{m}^{2} ;$ SD 7), and a slight majority of patients were males (53\% [136 of 258 patients and 159 of 300 hips]). The most prevalent underlying diagnosis was osteoarthritis, present in $73 \%$ of hips (219 of 300) (Table 1).

The M2a Taper has a wrought cobalt-chromium $18^{\circ}$ tapered insert that is impacted into a titanium porous plasma spray-coated outer shell and articulated with a wrought cobalt-chromium modular femoral head. The outer shell was available as either solid or with two dome holes for screws. Two screws were used for added fixation in $11 \%$ (34 of 300). The acetabular component design and manufacturing were constant and unchanged over the entire period of study. A direct lateral surgical approach was used in all cases, as previously described by Frndak et al. [14]. All femoral components used were the MalloryHead system (Biomet) with one cemented (MHC) and all other cementless porous (MHP). A lateralized offset option for the MHP became available in 1999 and was used in $38 \%$ (113 of 300). Femoral head diameters were $28 \mathrm{~mm}$ in $218(73 \%), 32 \mathrm{~mm}$ in 80 (27\%), and not noted in two. All devices used in this study were either used according to the approved protocol of the IDE study or cleared by the US FDA and used according to labeling provided.
Table 1. Demographics

\begin{tabular}{|c|c|}
\hline Characteristic & Frequency or mean \\
\hline Number of patients & 258 \\
\hline Number of hips & 300 \\
\hline \multicolumn{2}{|l|}{ Gender of patients } \\
\hline Males & 136 (53\%; 159 hips $)$ \\
\hline Females & 122 (47\%; 141 hips) \\
\hline Age (years) & $\begin{array}{l}57 \text { (range, } 24-85 \\
\quad \text { SD 11) }\end{array}$ \\
\hline Height (inches) & $\begin{array}{l}68 \text { (range, } 58-78 \\
\text { SD 4) }\end{array}$ \\
\hline Weight (pounds) & $\begin{array}{l}202 \text { (range, } 105-350 ; \\
\text { SD 51) }\end{array}$ \\
\hline Body mass index $\left(\mathrm{kg} / \mathrm{m}^{2}\right)$ & $\begin{array}{l}31 \text { (range, } 18-64 \\
\text { SD 7) }\end{array}$ \\
\hline \multicolumn{2}{|l|}{ Diagnosis } \\
\hline Osteoarthritis & $219(73 \%)$ \\
\hline Avascular necrosis & $36(12 \%)$ \\
\hline Developmental dysplasia & $14(5 \%)$ \\
\hline Posttraumatic arthritis & $11(4 \%)$ \\
\hline Rheumatoid arthritis & $9(3 \%)$ \\
\hline Legg-Calvé-Perthes & $7(2 \%)$ \\
\hline Slipped capital femoral epiphysis & $2(1 \%)$ \\
\hline Ankylosing spondylitis & $2(1 \%)$ \\
\hline \multicolumn{2}{|l|}{ Activity level } \\
\hline Sedentary & $2(1 \%)$ \\
\hline Semisedentary & $1(<1 \%)$ \\
\hline Light labor & $136(45 \%)$ \\
\hline Moderate manual labor & $122(41 \%)$ \\
\hline Heavy manual labor & $39(13 \%)$ \\
\hline \multicolumn{2}{|l|}{ Charnley classification } \\
\hline $\mathrm{A}=$ unilateral hip condition & $134(45 \%)$ \\
\hline $\mathrm{B}=$ bilateral hip condition & $117(39 \%)$ \\
\hline $\begin{array}{l}\mathrm{C}=\text { factors other than hip(s) that affect } \\
\text { walking function }\end{array}$ & $19(16 \%)$ \\
\hline
\end{tabular}

Postoperatively, patients were allowed immediate full weightbearing with the assistance of ambulatory aids. Ambulatory aids were discontinued when the patient could walk with minimal to no limp and without pain. All patients were instructed to use the same postoperative hip precautions for 6 weeks including to sleep on their back, use an elevated toilet seat, use a cushion in all low chairs, not to flex at the waist past $90^{\circ}$, and to avoid excessive adduction such as crossing one leg over the other.

Patients returned to our clinic for followup postoperatively at approximately 6 weeks and then were instructed to return annually thereafter or sooner if a problem arose. Patients were assessed at each evaluation using the Harris hip score [16] and, beginning in 2011, the UCLA activity score [2]. Patients presenting postoperatively with a painful 
MoM THA were evaluated in the same way as patients with painful THA of any bearing type with a clinical history including assessment of organs and systems for changes, physical examination with palpation around the hip to detect local swelling or soft tissue masses as well as functional assessment, plain radiographs, and laboratory testing to rule out infection searching for possible extrinsic as well as intrinsic causes [23]. Using a risk stratification process based on recommendations by the US FDA, The Hip Society, The American Association of Hip and Knee Surgeons (AAHKS), and the American Academy of Orthopaedic Surgeons (AAOS), if the patient with a smalldiameter MoM THA has pain that cannot be attributed to intrinsic causes such as loosening, infection, periprosthetic fracture, instability, bursitis, tendonitis, or any extrinsic causes such as spine disease, peripheral vascular or metabolic bone disease, hernia, malignancy, nerve injury, complex regional pain syndrome, or psychological illness, then suspicion is raised for ARMD [23, 27, 49]. Further testing should be performed to include screening for serum metal ion levels and cross-sectional imaging with metal artifact reduction sequence (MARS) MRI or ultrasound to evaluate for the presence of fluid collection and/or pseudotumor. For asymptomatic patients with a wellfunctioning small-diameter MoM-THA, failure risk is considered low, and the FDA recommends followup every 1 to 2 years but does not believe there is a clear need for routine screening of metal ions or soft tissue advanced imaging [49]. ARMD is a general, comprehensive term initially put forth by Langton et al. to describe failures of MoM arthroplasty bearings "associated with pain, a large sterile effusion of the hip and/or macroscopic necrosis/ metallosis" [24]. ARMD encompasses both aseptic lymphocytic-dominated vasculitis-associated lesions [50], which are based on histological diagnosis, and pseudotumors, which are soft tissue changes in surrounding tissues, often cystic or solid masses, that can be destructive to adjacent muscle and bone [41]. The diagnosis of ARMD is based on a combination of preoperative clinical history and physical examination and the intraoperative macroscopic and histologic appearance of the surrounding tissues. Clinical records and radiographs were reviewed to determine frequency and etiology of component revision. All patients had minimum 2-year followup (mean, 10 years; range, 2-19 years). No patients were recalled specifically for this study; all data were obtained from medical records and radiographs.

\section{Statistical Analysis and Study Size}

Analysis of device survival/failure times was displayed using Kaplan-Meier curves and significance testing was done using proportional hazards models. An initial exploratory univariate analysis was performed looking at several potential risk factors for revision: continuous risk factors were height, weight, body mass index, age, cup diameter, cup angle of inclination, use of screws, stem diameter, head diameter, preoperative Harris hip pain, and total scores; categorical risk factors were preoperative diagnosis, activity level, sex, and stem type. Those factors that were associated with $\mathrm{p}$ values $<0.2$ were used in a multivariable proportional hazards regression model and significance was assessed at the 0.05 level. Adjusted risk ratios and their $95 \%$ confidence intervals are reported for significant factors. All analyses were carried out using JMP/11 Pro ${ }^{\circledR}$ software (SAS Institute, Cary, NC, USA).

\section{Results}

The frequency of ARMD in this population was 5\% (14 of 300). Failures secondary to ARMD occurred at a mean of 11 years postoperative (range, 7-18 years) and had a general pattern: eight patients (10 hips) presented with late gradual onset of groin pain, weakness, normal radiographs, negative infection serology, and elevated serum cobaltchromium levels with five patients (six hips) noting subluxation and/or squeaking or grinding. Revisions in cases with mechanical symptoms were associated with catastrophic pseudotumor and soft tissue damage. The remaining ARMD revisions were two for acetabular fracture after falling, one with a grossly loose, migrated acetabular component, and one for femoral loosening, all of whom had bone loss, metallosis, and associated soft tissue changes present at the time of revision. A full revision was performed in two patients with associated femoral loosening, one apparent on preoperative radiographs and the other determined intraoperatively with provocative force. Isolated cup revision was performed in the other 12 hips. The liner/shell taper was not disassociated at the time of revision or after explantation unless screws were present. There were no signs of taper corrosion at the liner/ shell junction in any case; however, corrosion was noted at the head/taper junction in two patients (three hips) revised for ARMD.

In simple univariate analysis, female sex was associated with a higher frequency of failure resulting from all causes (10\% [14 of 141 hips in females] versus 4\% [six of 159 hips in males]; $\mathrm{p}=0.03$ ), but not for failure resulting from aseptic causes or failure attributable to ARMD. However, in multivariate analysis, neither sex nor any other variable tested could be proven as a risk factor for failure in this group. Taken together, the suggestion is that female patients may have more failures but do not fail any earlier than male patients. 


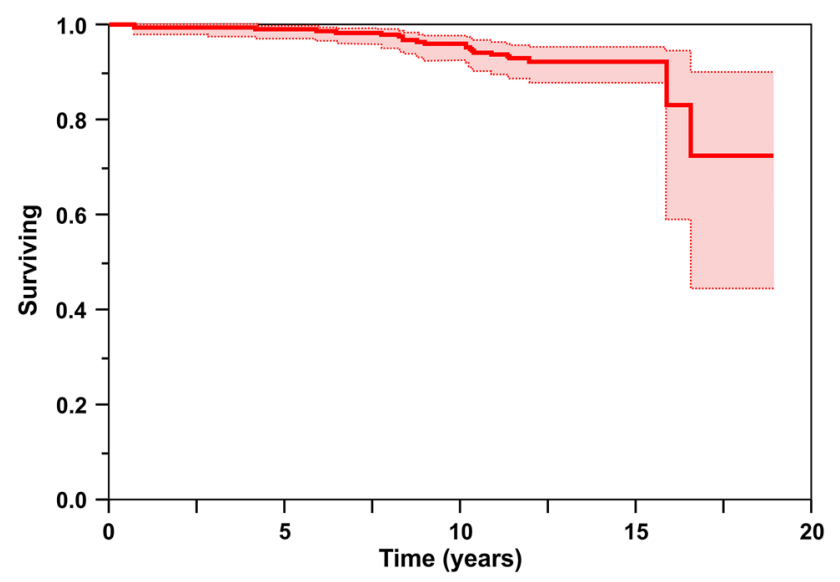

Fig. 2 Kaplan-Meier analysis revealed survival free of component revision for all causes was $95 \%$ at 10 years $(95 \% \mathrm{CI}, 91 \%-97 \%), 92 \%$ at 15 years $(95 \% \mathrm{CI}, 87 \%-95 \%)$, and $72 \%$ at 19 years $(95 \% \mathrm{CI}, 43 \%-$ $90 \%)$.

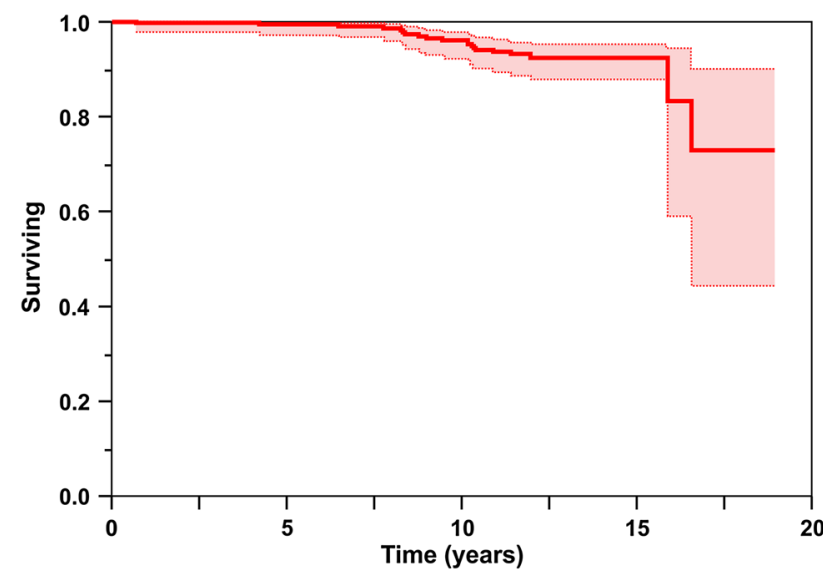

Fig. 3 Kaplan-Meier analysis revealed survival free of aseptic component revision was $96 \%$ at 10 years $(95 \% \mathrm{CI}, 92 \%-98 \%)$, $92 \%$ at 15 years $(95 \% \mathrm{CI}, 88 \%-95 \%)$, and $73 \%$ at 19 years $(95 \% \mathrm{CI}$, $43 \%-90 \%)$.

Kaplan-Meier analysis revealed survival free of component revision for any reason was $95 \%$ at 10 years (95\% confidence interval [CI], 91\%-97\%), 92\% at 15 years $(95 \% \mathrm{CI}, 87 \%-95 \%)$, and $72 \%$ at 19 years $(95 \%$ CI, 43\%-90\%) (Fig. 2), and survival free of component revision for aseptic causes was $96 \%$ at 10 years $(95 \% \mathrm{CI}$, $92 \%-98 \%), 92 \%$ at 15 years $(95 \% \mathrm{CI}, 88 \%-95 \%)$, and $73 \%$ at 19 years (95\% CI, 43\%-90\%) (Fig. 3). Twenty hips in 18 patients have undergone component revision (7\% [20 of 300]). Indications for revision were infection in two hips treated with two-staged exchange of all components, aseptic loosening/failure of ingrowth of the acetabular component in four hips, and ARMD in 14 hips (12 patients).

\section{Discussion}

Early reports with MoM THA devices, reintroduced in an effort to reduce failures secondary to osteolysis induced by polyethylene wear, were promising. In a report of the original FDA IDE study involving the design reported in this study (the Biomet M2a Taper), 11 centers reviewed 98 patients ( 99 hips; 46 polyethylene liners versus 53 metal liners) with minimum 5-year followup (mean, 5.7 years; range, 5-8 years) and reported no device-related complications, no dislocations, and no acetabular revisions or failures in either the study or control groups [30]. In light of this and other published reports at the time documenting success with MoM devices, on FDA clearance in 2000, we began using MoM bearings in the majority of our patients undergoing primary THA, particularly those who were younger and more active. In 2002 as MoM articulations with larger heads and monoblock shells became available, we began to transition away from the M2a Taper toward the newer MoM devices with greater ROM that we hoped would provide additional protection against impingement, instability, and dislocation. We began to observe early failures resulting from ARMD in our patients with largediameter MoM THA along with concurrent reports in the literature, but did not encounter any such failures in our patients with small-diameter head MoM THA devices until 2008 in a patient 7 years postoperatively. Published guidelines for management of patients after MoM THA suggest that small-diameter MoM THAs are at low risk for ARMD [23, 27, 49], but perhaps the risk increases with longer time in vivo. In this report we analyzed the longterm (mean, 10 years) results with this smaller diameter head MoM device to ascertain the frequency of ARMD, risk factors for ARMD in this population, and survival of the prosthesis.

The first limitation of our study is that it was retrospective and therefore may be subject to selection bias. We tended to use MoM devices in our younger, more active, and more high-demand patients. Perhaps the higher activity levels in these patients resulted in higher rates of wear, although we could not determine a correlation between activity level and component failure through multivariate analysis. Another weakness of the study is that in addition to 18 patients ( 15 hips) who died before a 2 -year clinical assessment, minimum followup was not available for 29 hips in 26 presumed living patients. Attempts were made to contact the patients at their last known address and phone numbers, by contacting referring and family physicians listed, and by searching available free Internet services. However, minimum 2-year clinical followup was available for $86 \%$ of patients. A further weakness of the study is that we do not know how many asymptomatic patients in the overall group may have ARMD because we do not 
routinely order serum metal ion testing or MARS MRI studies in asymptomatic patients with this device per FDA, AAOS, and AAHKS guidelines. However, in four patients with revised hips diagnosed intraoperatively as having ARMD based on findings of metallosis and macroscopic soft tissue and bony changes, the preoperative diagnosis for revision was based on other reasons: acute acetabular fracture in two, femoral loosening in one, and gross acetabular loosening with migration in one.

Our results and those of other published studies demonstrate that ARMD does occur with small-diameter heads in MoM THA [5, 8, 12, 19, 20, 39, 44, 48]. Unlike large-diameter MoM THA, in which aseptic loosening and early failure of ingrowth appear to be the main failure modes with ARMD appearing in the early to midterm, MoM THA with a titanium shell and cobalt-chromium insert had very low rates of aseptic loosening. In a study from our center of large-diameter MoM THA from the same manufacturer as the current study device (Magnum and M2a-38; Zimmer Biomet), the frequency of ARMD was 3\% (47 of 1440) and aseptic loosening was 2\% (34 of 1440) at a mean followup of 7 years (range, 2-12 years) [28]. In comparison, in the current study the frequency of ARMD was 5\% (14 of 300) at a mean followup of 10 years (range, 2-19 years), but frequency of revision for aseptic loosening was much lower at $1 \%$ (four of 300). In an investigation into frequency of ARMD after MoM THA performed from 2000 to 2011 in Japan that involved questionnaires returned from 82 hospitals, ARMD was reported in $1.2 \%$ of THAs (160 of 12,961) [48]. The frequency in 28-mm Metasul bearings was $0.5 \%$ (seven of 1535). For the seven other devices included, small- and large-diameter bearings were grouped together by brand, including the M2a-Taper with 28- and 32-mm heads and Magnum (38-54 mm). The combined frequency of ARMD for the Biomet M2a bearings was $0.9 \%$ (24 of 2777). Using the Metasul group as a control, frequency of ARMD was significantly elevated with Ultamet (DePuy, Tokyo, Japan; $1.3 \%$ [63 of 4744]; $\mathrm{p}=0.005$ ), Conserve (Wright Medical, Tokyo, Japan; 2.2\% [37 of 1701]; $\mathrm{p}<0.001$ ), and Cormet (Corin, Osaka, Japan; 3.1\% [15 of 491]; p < 0.001) bearings. In a study of the 32-mm Lubrimet MoM bearing (Smith \& Nephew, Rotkreuz, Switzerland) at minimum 10-year followup (mean, 11 years; range, 10-12 years), frequency of ARMD was 6\% (six of 100) [39]. In other studies of the Metasul bearing, reported frequencies of ARMD were $2.6 \%$ (three of 125) at 3 to 9 years followup [8], 3\% (one of 33) at mean followup of 5 years (range, 3-5 years) [5], and $2.4 \%$ (two of 85 ) at a mean followup of 11 years (10-12 years) [12]. In a report by Hwang et al of 141 patients (180 hips) with Metasul bearings reviewed at mean followup of 14 years (range, 12-18 years), nine hips had symptomatic groin pain with pseudotumor diagnosed in two (1.1\% [two of 180]) [20]. In light of their findings the authors performed CT evaluation on 111 willing patients (142 nonrevised hips) with mean 15-year followup (range, 13-19 years) and observed pseudotumors in 20\% (28 of 142), including 25 solid and three cystic, with 26 asymptomatic and only two that were symptomatic [21]. Roessler et al described a case report of arthroprosthetic

Table 2. Studies reporting long-term survivorship (mean followup $\geq 10$ years) of patients with small diameter metal-on-metal THA

\begin{tabular}{|c|c|c|c|c|c|}
\hline Studies and year & $\begin{array}{l}\text { Patients (hips), special } \\
\text { circumstances }\end{array}$ & Articulation & $\begin{array}{l}\text { Bearing } \\
\text { diameter } \\
(\mathrm{mm})\end{array}$ & $\begin{array}{l}\text { Mean } \\
\text { followup } \\
\text { (years; range) }\end{array}$ & $\begin{array}{l}\text { Survivorship, revision for all } \\
\text { causes }\end{array}$ \\
\hline Grübl et al., 2007 [15] & 73 & Metasul & 28 & Minimum 10 & $99 \%$ at 10 years \\
\hline Eswaramoorthy et al., 2008 [12] & $82(85)$ & Metasul & 28 & $11(10-12)$ & $94 \%$ at 10 years \\
\hline Neumann et al., 2010 [39] & $93(94)$ & Lubrimet & 32 & $11(10-12)$ & $93 \%$ at 12 years \\
\hline Park et al., 2010 [42] & $\begin{array}{l}37(39) \text {, cementless titanium } \\
(\mathrm{n}=21) \text { versus cemented } \\
\text { matte iron alloy }(\mathrm{n}=18) \\
\text { stems }\end{array}$ & Metasul & 28 & $10(10-12)$ & $\begin{array}{l}81 \% \text { at } 10 \text { years; cementless } \\
\text { stems- }-100 \% \text { at } 10 \text { years; } \\
\text { cemented stems-61\% at } 10 \\
\text { years }\end{array}$ \\
\hline Saito et al., 2010 [45] & $77(90)$ & Metasul & 28 & $12(10-14)$ & $94 \%$ at 12 years \\
\hline Dastane et al., 2011 [10] & $66(69)$ & Metasul & 28 & $13(8-16)$ & $92 \%$ at 16 years \\
\hline Hwang et al. 2011 [19] & $70(78)$ age $\leq 50$ years & Metasul & 28 & $12(11-14)$ & $99 \%$ at 13 years \\
\hline Migaud et al., 2011 [35] & 30 (39) age $\leq 50$ years & Metasul & 28 & $13(12-14)$ & $100 \%$ at 12 years \\
\hline Randelli et al., 2012 [43] & $100(138)$ & Metasul & 28 & $13(11-14)$ & $\begin{array}{c}98 \% \text { at } 5 \text { years, } 95 \% \text { at } 10 \\
\text { years, } 94 \% \text { at } 14 \text { years }\end{array}$ \\
\hline Hwang et al., 2013 [20] & $141(180)$ age $\leq 56$ years & Metasul & 28 & $14(12-18)$ & $98 \%$ at 18 years \\
\hline Innmann et al., 2014 [22] & $91(100)$ age $\leq 50$ years & Metasul & 28 & $12(10-15)$ & $91 \%$ at 13 years \\
\hline Current study, 2015 & $258(300)$ & M2a-Taper & 28,32 & $10(2-19)$ & $\begin{array}{c}95 \% \text { at } 10 \text { years, } 92 \% \text { at } 15 \\
\text { years, } 72 \% \text { at } 19 \text { years }\end{array}$ \\
\hline
\end{tabular}


cobaltism and pseudotumor in a 75-year-old man who presented 14 years after primary THA with a $28-\mathrm{mm}$ Metasul bearing complaining of chronic subluxation, recurrent movement-specific pain, and concomitant atopic eczema [44]. Intraoperative findings at revision revealed a highly worn cobalt-chromium head.

Published reports specifically describing risk factors for revision after small-diameter MoM THA are sparse. In the current study female sex was identified in univariate analysis as associated with a higher frequency of revision for any cause ( $10 \%$ versus $4 \%$ in males; $p=0.03$ ), but not for revision for aseptic causes or revision for ARMD. Furthermore, multivariate analysis did not prove sex or any other variable tested as a risk factor for revision. In earlier studies from our center, one involving all MoM THAs with both large- and small-diameter heads through 2006, and the other with longer followup and involving only MoM THAs with large-diameter $(\geq 36 \mathrm{~mm})$ heads, we observed a higher frequency of failure in female patients [25, 28]. Likewise, the Australian National Joint Replacement Registry demonstrated higher risk of revision in females than males after primary MoM THA with head sizes $>32 \mathrm{~mm}$ but no appreciable difference with head sizes $\leq 32 \mathrm{~mm}$ [3].

In our study Kaplan-Meier analysis revealed survival free of component revision for any reason was $95 \%$ at 10 years, $92 \%$ at 15 years, and $72 \%$ at 19 years, and survival free of component revision for aseptic causes was $96 \%$ at 10 years, $92 \%$ at 15 years, and $73 \%$ at 19 years. Several studies have reported good results with the Metasul at followup of more than 10 years with survival ranging from $81 \%$ to $100 \%$ (Table 2) [10, 12, 15, 20, 22, 35, 42, 43, 45]. Two other studies have reported mid- to long-term followup for small-diameter MoM THA devices other than Metasul [36, 39]. Milosev et al reported on 563 patients (611 hips) with a 28-mm Sikomet (Plus Orthopedics, Rotkreuz, Switzerland) at a mean followup of 7 years (range, 2-11 years) [36]. They observed survival free or revision for any cause of $91 \%$ (95\% CI, 88\%-95\%) at 10 years. With the 32-mm Lubrimet bearing in 99 patients (100 hips) at mean followup of 11 years (range, 10-12 years), Neumann et al reported 93\% (95\% CI, 89\%-99\%) survival free of revision for any cause and $96 \%$ survival free of revision for aseptic loosening at 12 years [39].

Overall, the frequency of ARMD with this device was low but represented $70 \%$ (14 of 20) of revisions performed. The late onset and devastating nature of these metal-related failures is concerning. We have discontinued the use of all MoM devices in our practice. Patients with MoM devices, like all patients with total joint arthroplasties, should be encouraged to return for clinical and radiographic followup, preferably on an annual basis. Symptomatic patients require a thorough workup and vigilant observation for ARMD with serum metal ion testing and cross- sectional imaging using either MARS MRI or ultrasound. We recommend a low threshold to perform a systematic evaluation of patients with MoM THA because early recognition and diagnosis will facilitate the initiation of appropriate treatment before significant adverse biological reactions and soft tissue damage occurs.

Acknowledgments We thank Gerald R. Hobbs $\mathrm{PhD}$, for his assistance in performing statistical analysis for this study.

\section{References}

1. Althuizen MN, V Hooff, Miranda L, v d Berg-v Erp SH, V Limbeek J, Nijhof MW. Early failures in large head metal-onmetal total hip arthroplasty. Hip Int. 2012;22:641-647.

2. Amstutz HC, Thomas BJ, Jinnah R, Kim W, Grogan T, Yale C. Treatment of primary osteoarthritis of the hip. A comparison of total joint and surface replacement arthroplasty. $J$ Bone Joint Surg Am. 1984;66:228-241.

3. Australian Orthopaedic Association National Joint Replacement Registry. Metal on metal total conventional hip arthroplasty, Supplementary Report 2013. Available at: https://aoanjrr.dmac. adelaide.edu.au/documents/10180/127369/Metal\%20on\%20Metal\% 20Total\%20Conventional\%20Hip\%20Arthroplasty. Accessed February 18, 2014.

4. Bernstein M, Desy NM, Petit A, Zukor DJ, Huk OL, Antoniou J. Long-term follow-up and metal ion trend of patients with metalon-metal total hip arthroplasty. Int Orthop. 2012;36:1807-1812.

5. Bisseling P, Smolders JM, Hol A, van Susante JL. Metal ion levels and functional results following resurfacing hip arthroplasty versus conventional small-diameter metal-on-metal total hip arthroplasty; a 3 to 5 year follow-up of a randomized controlled trial. J Arthroplasty. 2015;30:61-67.

6. Bosker BH, Ettema HB, Boomsma MF, Kollen BJ, Maas M, Verheyen CC. High incidence of pseudotumour formation after large-diameter metal-on-metal total hip replacement: a prospective cohort study. J Bone Joint Surg Br. 2012;94:755-761.

7. Brodner W, Bitzan P, Meisinger V, Kaider A, Gottsauner-Wolf F, Kotz R. Serum cobalt levels after metal-on-metal total hip arthroplasty. J Bone Joint Surg Am. 2003;85:2168-2173.

8. Carr AM, DeSteiger R. Osteolysis in patients with a metal-onmetal hip arthroplasty. A N Z J Surg. 2008;78:144-147.

9. Cuckler JM, Moore KD, Lombardi AV Jr, McPherson E, Emerson R. Large versus small femoral heads in metal-on-metal total hip arthroplasty. J Arthroplasty. 2004;19(Suppl 3):41-44.

10. Dastane M, Wan Z, Deshmane P, Long WT, Dorr LD. Primary hip arthroplasty with 28-mm Metasul articulation. J Arthroplasty. 2011;26:662-664.

11. Dorr LD, Wan Z, Longjohn DB, Dubois B, Murken R. Total hip arthroplasty with use of the Metasul metal-on-metal articulation. Four to seven-year results. J Bone Joint Surg Am. 2000;82:789798.

12. Eswaramoorthy V, Moonot P, Kalairajah Y, Biant LC, Field RE. The Metasul metal-on-metal articulation in primary total hip replacement: clinical and radiological results at ten years. $J$ Bone Joint Surg Br. 2008;90:1278-1283.

13. Fehring TK, Odum S, Sproul R, Weathersbee J. High frequency of adverse local tissue reactions in asymptomatic patients with metal-on-metal THA. Clin Orthop Relat Res. 2014;472:517-522.

14. Frndak PA, Mallory TH, Lombardi AV Jr. Translateral surgical approach to the hip. The abductor muscle 'split.' Clin Orthop Relat Res. 1993;295:135-141. 
15. Grübl A, Marker M, Brodner W, Giurea A, Heinze G, Meisinger $\mathrm{V}$, Zehetgruber H, Kotz R. Long-term follow-up of metal-onmetal total hip replacement. J Orthop Res. 2007;25:841-848.

16. Harris WH. Traumatic arthritis of the hip after dislocation and acetabular fractures: treatment by mold arthroplasty. An end-result study using a new method of result evaluation. $J$ Bone Joint Surg Am. 1969;51:737-755.

17. Hasegawa M, Yoshida K, Wakabayashi H, Sudo A. Cobalt and chromium ion release after large-diameter metal-on-metal total hip arthroplasty. J Arthroplasty. 2012;27:990-996.

18. Hasegawa M, Yoshida K, Wakabayashi H, Sudo A. Prevalence of adverse reactions to metal debris following metal-on-metal THA. Orthopedics. 2013;36:e606-612.

19. Hwang KT, Kim YH, Kim YS, Choi IY. Cementless total hip arthroplasty with a metal-on-metal bearing in patients younger than 50 years. J Arthroplasty. 2011;26:1481-1487.

20. Hwang KT, Kim YH, Kim YS, Choi IY. Is second generation metal-on-metal primary total hip arthroplasty with a $28 \mathrm{~mm}$ head a worthy option? A 12- to 18-year follow-up study. J Arthroplasty. 2013;28:1828-1833.

21. Hwang KT, Kim YH, Kim YS, Ryu JA. Prevalence of a softtissue lesion after small head metal-on-metal total hip replacement: 13- to 19-year follow-up study. Bone Joint J. 2014;96:1594-1599.

22. Innmann MM, Gotterbarm T, Kretzer JP, Merle C, Ewerbeck V, Weiss S, Aldinger PR, Streit MR. Minimum ten-year results of a 28-mm metal-on-metal bearing in cementless total hip arthroplasty in patients fifty years of age and younger. Int Orthop. 2014;38:929-934.

23. Kwon YM, Lombardi AV, Jacobs JJ, Fehring TK, Lewis CG, Cabanela ME. Risk stratification algorithm for management of patients with metal-on-metal hip arthroplasty: consensus statement of the American Association of Hip and Knee Surgeons, the American Academy of Orthopaedic Surgeons, and the Hip Society. J Bone Joint Surg Am. 2014;96:e4(1-6).

24. Langton DJ, Jameson SS, Joyce TJ, Hallab NJ, Natu S, Nargol AV. Early failure of metal-on-metal bearings in hip resurfacing and large-diameter total hip replacement: a consequence of excess wear. J Bone Joint Surg Br. 2010;92:38-46.

25. Latteier MJ, Berend KR, Lombardi AV Jr, Ajluni AF, Seng BE, Adams JB. Gender is a significant factor for failure of metal-onmetal total hip arthroplasty. J Arthroplasty. 2011;26(Suppl):19-23.

26. Levy YD, Ezzet KA. Poor short term outcome with a metal-onmetal total hip arthroplasty. J Arthroplasty. 2013;28:1212-1217.

27. Lombardi AV Jr, Barrack RL, Berend KR, Cuckler JM, Jacobs JJ, Mont MA, Schmalzried TP. The Hip Society: algorithmic approach to diagnosis and management of metal-on-metal arthroplasty. J Bone Joint Surg Br. 2012;94(Suppl A):14-18.

28. Lombardi AV Jr, Berend KR, Morris MJ, Adams JB, Sneller MA. Large-diameter metal-on-metal total hip arthroplasty: dislocation infrequent but survivorship poor. Clin Orthop Relat Res. 2015;473:509-520.

29. Lombardi AV Jr, Mallory TH, Alexiades MM, Cuckler JM, Faris PM, Jaffe KA, Keating EM, Nelson CL Jr, Ranawat CS, Williams J, Wixson R, Hartman JF, Capps SG, Kefauver CA. Short-term results of the M2a-taper metal-on-metal articulation. J Arthroplasty. 2001;16(Suppl 1):122-128.

30. Lombardi AV Jr, Mallory TH, Cuckler JM, Williams J, Berend KR, Smith TM. Mid-term results of a polyethylene-free metal-onmetal articulation. J Arthroplasty. 2004;19(Suppl 2):42-47.

31. Long WT. The clinical performance of metal-on-metal as an articulation surface in total hip replacement. Iowa Orthop J. 2005;25:10-16.

32. MacDonald SJ. Metal-on-metal total hip arthroplasty: the concerns. Clin Orthop Relat Res. 2004;429:86-93.
33. MacDonald SJ, McCalden RW, Chess DG, Bourne RB, Rorabeck $\mathrm{CH}$, Cleland D, Leung F. Metal-on-metal versus polyethylene in hip arthroplasty: a randomized clinical trial. Clin Orthop Relat Res. 2003;406:282-296.

34. Migaud H, Putman S, Combes A, Berton C, Bocquet D, Vasseur L, Girard J. Metal-on-metal bearing: is this the end of the line? We do not think so. HSS J. 2012;8:262-269.

35. Migaud H, Putman S, Krantz N, Vasseur L, Girard J. Cementless metal-on-metal versus ceramic-on-polyethylene hip arthroplasty in patients less than fifty years of age: a comparative study with twelve to fourteen-year follow-up. J Bone Joint Surg Am. 2011;93(Suppl 2):137-142.

36. Milosev I, Trebse R, Kovac S, Cör A, Pisot V. Survivorship and retrieval analysis of Sikomet metal-on-metal total hip replacements at a mean of seven years. J Bone Joint Surg Am. 2006;88:1173-1182.

37. Mokka J, Junnila M, Seppänen M, Virolainen P, Pölönen T, Vahlberg T, Mattila K, Tuominen EK, Rantakokko J, Aärimaa V, Kukkonen J, Mäkelä KT. Adverse reaction to metal debris after ReCap-M2A-Magnum large-diameter-head metal-on-metal total hip arthroplasty. Acta Orthop. 2013;84:549-554.

38. Munro JT, Masri BA, Duncan CP, Garbuz DS. High complication rate after revision of large-head metal-on-metal total hip arthroplasty. Clin Orthop Relat Res. 2014;472:523-528.

39. Neumann DR, Thaler C, Hitzl W, Huber M, Hofstädter T, Dorn U. Long-term results of a contemporary metal-on-metal total hip arthroplasty: a 10-year follow-up study. J Arthroplasty. 2010;25: 700-708.

40. Nikolaou VS, Petit A, Debiparshad K, Huk OL, Zukor DJ, Antoniou J. Metal-on-metal total hip arthroplasty-five- to 11-year follow-up. Bull NYU Hosp Jt Dis. 2011;69(Suppl 1):S77-83.

41. Pandit H, Glyn-Jones S, McLardy-Smith P, Gundle R, Whitwell D, Gibbons CL, Ostlere S, Athanasou N, Gill HS, Murray DW. Pseudotumours associated with metal-on-metal hip resurfacings. J Bone Joint Surg Br. 2008;90:847-851.

42. Park MS, Chung WC, Yoon SJ, Cho HM, Kwon SH. Eleven-year follow-up of second-generation metal-on-metal total hip arthroplasty. J Orthop Surg (Hong Kong). 2010;18:15-21.

43. Randelli F, Banci L, D’Anna A, Visentin O, Randelli G. Cementless Metasul metal-on-metal total hip arthroplasties at 13 years. J Arthroplasty. 2012;27:186-192.

44. Roessler PP, Witt F, Efe T, Schmitt J. Arthroprosthetic cobaltism and pseudotumour also occur in patients with small diameter femoral ball head metal-on-metal total hip arthroplasties. BMJ Case Rep. 2014 Mar 28. doi:10.1136/bcr-2013-203362.

45. Saito S, Ishii T, Mori S, Hosaka K, Ootaki M, Tokuhashi Y. Long-term results of Metasul metal-on-metal total hip arthroplasty. Orthopedics. 2010;33:548.

46. Shahrdar C. Pseudotumor in large-diameter metal-on-metal total hip articulation. J Arthroplasty. 2011;26:665.e21-23.

47. Stryker LS, Odum SM, Fehring TK, Springer BD. Revisions of monoblock metal-on-metal THAs have high early complication rates. Clin Orthop Relat Res. 2015;473:469-474.

48. Sugano N, Iida H, Akiyama H, Takatori Y, Nagoya S, Hasegawa M, Kabata T, Hachiya Y, Yasunaga Y. Nationwide investigation into adverse tissue reactions to metal debris after metal-on-metal total hip arthroplasty in Japan. J Orthop Sci. 2014;19:85-89.

49. US Food and Drug Administration. Information for Orthopaedic Surgeons. Available at: http://www.fda.gov/MedicalDevices/ ProductsandMedicalProcedures/ImplantsandProsthetics/Metalon MetalHipImplants/ucm241667.htm\#3. Accessed August 6, 2015.

50. Willert HG, Buchhorn GH, Fayyazi A, Flury R, Windler M, Köster G, Lohmann CH. Metal-on-metal bearings and hypersensitivity in patients with artificial hip joints. A clinical and histomorphological study. J Bone Joint Surg Am. 2005;87:28-36. 
51. Wyles CC, Van Demark RE 3rd, Sierra RJ, Trousdale RT. High rate of infection after aseptic revision of failed metal-onmetal total hip arthroplasty. Clin Orthop Relat Res. 2014;472:509-516.
52. Wynn-Jones H, Macnair R, Wimhurst J, Chirodian N, Derbyshire B, Toms A, Cahir J. Silent soft tissue pathology is common with a modern metal-on-metal hip arthroplasty. Acta Orthop. 2011; 82:301-307. 